\title{
Cardiac Ischemia and Ischemia/Reperfusion Cause Wide Proteolysis of the Coronary Endothelial Luminal Membrane: Possible Dysfunctions
}

\author{
Blanca Arroyo-Flores ${ }^{1}$, Erika Chi-Ahumada ${ }^{1}$, Erika Briones-Cerecero ${ }^{2}$, Alma Barajas-Espinosa ${ }^{1}$, \\ Sandra Perez-Aguilar ${ }^{1}$, Ana Barba de la Rosa ${ }^{2}$, Maureen Knabb ${ }^{3}$ and Rafael Rubio ${ }^{1, *}$ \\ ${ }^{l}$ Departamento de Fisiologia y Farmacologia, Universidad Autonoma de San Luis Potosi, San Luis Potosi, Mexico \\ ${ }^{2}$ Departamento de Biologia Molecular, Instituto Potosino de Investigacion Cientifica y Tecnologica, San Luis Potosi, \\ Mexico \\ ${ }^{3}$ Department of Biology, West Chester University, West Chester, PA, USA
}

\begin{abstract}
Background: Ischemia and ischemia-reperfusion (I/R) are common clinical insults that disrupt the molecular structure of coronary vascular endothelial luminal membrane (VELM) that result in diverse microvasculature dysfunctions. However, the knowledge of the associated biochemical changes is meager. We hypothesized that ischemia and I/R-induced structural and functional VELM alterations result from biochemical changes. First, these changes need to be described and later the mechanisms behind be identified.

Methods: During control conditions, in isolated perfused rat hearts VELM proteins were labeled with biotin. The groups of hearts were: control (C), no flow ischemia (I; $25 \mathrm{~min}$ ), and I/R (I; $25 \mathrm{~min}$, reperfusion $30 \mathrm{~min}$ ). The biotinylated luminal endothelial membrane proteins in these three different groups were examined by 2-D electrophoresis and identified. But, it must be kept in mind the proteins were biotin-labeled during control.

Results: A comparative analysis of the protein profiles under the 3 conditions following $2 \mathrm{D}$ gel electrophoresis showed differences in the molecular weight distribution such that $\mathrm{MW}_{\mathrm{C}}>\mathrm{MW}_{\mathrm{I}}>\mathrm{MW}_{\mathrm{I} / \mathrm{R}}$. Similar analysis for isoelectric points $\left(\mathrm{pH}_{\mathrm{i}}\right)$ showed a shift toward more acidic $\mathrm{pH}_{\mathrm{i}}$ under ischemic conditions. Of $100 \%$ proteins identified during control $66 \%$ and $88 \%$ changed their $\mathrm{MW}-\mathrm{pH}_{\mathrm{i}}$ during ischemia and $\mathrm{I} / \mathrm{R}$ respectively. Among these lost proteins there were 9 proteins identified as adhesins and G-protein coupled receptors.

General significance: I and $\mathrm{I} / \mathrm{R}$ insults alter $\mathrm{MW}-\mathrm{pH}_{\mathrm{i}}$ of most luminal glycocalyx proteins due to the activation of nonspecific hydrolizing mechanisms; suspect metalloproteases and glycanases. This makes necessary the identification of hydrolyzing enzymes reponsible of multiple microvascular dysfunctions in order to maintain the integrity of vascular endothelial membrane. VELM must become a target of future therapeutics.
\end{abstract}

Keywords: Luminal endothelial membrane, G-protein coupled receptors, Adhesins, Metalloproteases, Glycanases, Luminal endothelial solutes exclusion zone.

\section{INTRODUCTION}

Clinically myocardial ischemia and ischemia/reperfusion (I/R) insults; a scientific and a major clinical problem [1], indiscriminatingly occur during cardiac transplant, coronary bypass, angioplasties, thrombolysis, open heart surgery and all interventions that result in transient interruption of an organ circulation. All these beneficial procedures have brought relieve to millions of patients, but, the associated I/R insult causes diverse cardiac dysfunctions whose mechanisms, by not being well understood prevent correct treatments. I/R injure different cell types and their organelles [2-8]. However, the coronary vascular endothelial luminal membrane (VELM) despite its role on infarct size [10, 12, 13],

\footnotetext{
*Address correspondence to this author at the Department of Physiology, Facility of Medicine, Universidad Autonoma de San Luis Potosi, Av. Venustiano Carranza 2405, Los Filtros, San Luis Potosí, SLP 78216, Mexico; Tel: 52444826 2455; E-mail: rrubio@uaslp.mx
}

it is suspect $\mathrm{I} / \mathrm{R}$ induce important chemical structural changes and as compared to these changes in other organelles [2-5, 8, 9], VELM changes are unknown.

VELM or "luminal endothelial glycocalyx", is a molecular complex composed of a large variety of extracellular domains of transmembrane proteins, glycoproteins, proteoglycans, glycosaminoglycans and matrix bound plasma proteins [13-16], consequently in the VELM reside multiple normal and pathological functions; solute wall permeation, flow sensing, hormone reception, coagulation, atherosclerosis etc [7,12,13,17-19, 21-23]. All these endothelial luminal functions are disturbed by ischemia and I/R and associated oxygen radicals $[1,20,24]$. The luminal endothelial glycocalyx has a thickness estimated between $0.2-0.8 \mu \mathrm{m}[11-14,18$, 20]. In living microcirculatory preparations in which fluorescently labeled dextran of various sizes ( 50 to $2,000 \mathrm{kD}$ ) were infused intraarterially. Fluorescence distributed uniformly in most of the lumen of blood vessels, but was absent in a zone 
$0.2-0.8 \mu \mathrm{m}$ thick adjacent to the vessel wall, an "endothelial exclusion zone" (EEZ). Infusion of dextrans of lower molecular weight resulted in a deeper penetration implying that EEZ constitutes a barrier for solute difussion likely the result of a restricted diffusion through densely packed molecules [18, 20, 24-26].

Conditions that lead to a EEZ decrease, a deeper solute diffusion through the VELM, can be acheived by treatment with oligosaccharide hydrolyzing enzymes, hyaluronidase [20, 24, 25] and heparinase [27], and by treatment with inflammatory stimuli such as oxidized low-density lipoproteins [28], TNF- $\alpha$ [26] and oxidative stress [20]. EEZ decrease is the early step in the inflammatory cascade associated with $\mathrm{I} / \mathrm{R}$ injury that results in endothelial dysfunction $[10,12,13$, $17,24]$. Thus, diverse stimuli can alter the VELM structure as a result of a still undescribed change in chemical composition. We hypothesized that ischemia and I/R-induced structural and functional VELM alterations result from biochemical changes that firstly need to be described, later identify the mechanisms behind. This strategy will lead to successful medical treatments.

To isolate with high purity coronary VELM proteins we adopted a novel strategy; in situ VELM protein biotinylation [29]. Experiments were performed in retrogradely perfused isolated rat hearts. Selectively Biotin-labeled coronary VELM proteins from myocardial tissue homogenates were purified and identified. The biotin-labeled coronary VELM proteins were identified either by two-dimensional gel electrophoresis followed by Western blot or by passing the tissue membrane fraction through a Streptavidin-Biotin affinity chromatography column. We found that ischemia and I/R stimuli produced alterations of most coronary VELM protein molecular weight (MW) and their isoelectric point profiles, but I/R insult caused the more drastic changes.

\section{MATERIALS AND METHODS (FOR DETAILS SEE SUPPLEMENTAL MATERIAL)}

Hearts were removed and coronaries retrogradely perfused [22, 23]. Thereafter, VELM proteins were selectively labeled by intracoronary perfusion of biotin during control conditions. After biotin labeling period, hearts were perfused with buffer and processed for immunohistochemical identification of biotin in tissue sections (brown color).

In three groups of hearts coronary VELM was biotin labeled during control period, thereafter biotin exccess was wash off with PBS. One group of hearts was inmediately processed for tissue protein extraction (control group), a secong group was subjected to $25 \mathrm{~min}$ of ischemia and tissue protein extracted (ischemia group) and the third group was subjected to $25 \mathrm{~min}$ ischemia, followed by a $30 \mathrm{~min}$ reperfusion period (I/R group), thereafter processed for tissue protein extraction. Tissues were homogenized and whole tissue cardiac membranes (CM) were isolated, divided into 2 aliquots to identify coronary VELM proteins, one aliquot was processed for SDS-2D gel electrophoresis and Western blot [30] to identify biotin-labeled VELM proteins (procedure No 1). The second CM aliquot was applied to monomeric avidin affinity column and bound biotinylated proteins were eluted with D-biotin in PBS; VELM fraction (proce- dure No 2). The SDS-2D gel results obtained with both procedures were the same.

On control coronary VELM protein fraction dot Immunoblots were performed, dots were incubated with a primary antibody, follow by a secondary antibody coupled to HRP rinsed and DAB was used to develop HRP color reaction. Twelve specific antigens were identified.

\section{RESULTS}

\subsection{Biotinylation of Coronary Vascular Endothelial Membrane Proteins}

The heart tissue sections were examined by inmunohistochemical microscopy to verify if biotin was confined to the vascular endothelium. The perfused heart was well preserved morphologically (Fig. 1A, control) and when revealed with DAB intense staining was restricted to the endothelium of all blood vessels, with prominent capillary labeling (Fig 1B and 1C). This indicates the vascular bed was well perfused and most of the vascular endothelial membrane was biotinylated.

\subsection{SDS-PAGE Protein Profile Ladders}

Two equal aliquots of CM proteins were loaded on two separate SDS-PAGE gels and run. Thereafter, one gel was stained with Sypro Ruby (CM, Fig. 1D) and the other gel was blotted to nitrocellulose membrane and developed for biotin (VELM, Fig. 1E). Fig. (1D) show different protein profiles, the CM proteins of control $(\mathrm{C})$, and the two injury conditions, ischemia (I) and I/R heart (IR). The CM protein ladder profiles from control and ischemic hearts show differences that became more striking in the I/R fraction, with increased number of low molecular weight bands. The biotin-labeled VELM protein profile ladders are shown in Fig. (1E). As in the case of Fig. (1D), protein ladder profiles of $\mathrm{I} / \mathrm{R}$ hearts show striking differences in the number of low molecular weight bands compared to control.

\subsection{Western Blot Biotin Analysis}

To determine in coronary VELM proteins the individual changes induced by ischemia and I/R, the CM proteins subjected to 2D SDS-PAGE were electro-transferred to nitrocellulose membranes and developed with HRP-streptavidinDAB (Fig. 2). Individual protein profile distributions of coronary VELM differences between individual protein between control (Fig. 2A) and ischemia (Fig. 2B) are noticeable, but more striking differences appear in I/R group (Fig. 2C). These data show that ischemia and $I / R$ injuries affect MW and $\mathrm{pH}_{\mathrm{i}}$ of many individual coronary VELM proteins of the rat heart.

By dot blot, the following 12 proteins were identified in the VELM protein fraction: the hormone receptors for adenosine $A_{1}$ and $A_{2 A}$, thromboxane $A_{2}\left(T_{X} A_{2}\right)$, endothelin ETA, adrenergic $\alpha_{1}$ and $\beta_{1}$, Angiotensin $\mathrm{AT}_{1}$, prolactin PRL, and bradykinin $\mathrm{B}_{2}$, the channel $\beta E$ EnaC and the adhesive proteins PECAM-1, VCAM-1 and ICAM-1. All these VELM proteins gave a positive dot blot reaction (Fig. 3). Of this list for $\alpha_{1}, \beta_{1}, \mathrm{AT}_{1}$, PRL, B,$\beta$ EnaC, PECAM-1, VCAM-1, and ICAM-1 their corresponding molecular weigths (MW) and isoelectric points $\left(\mathrm{pH}_{\mathrm{i}}\right)$ have been reported. Protein points 


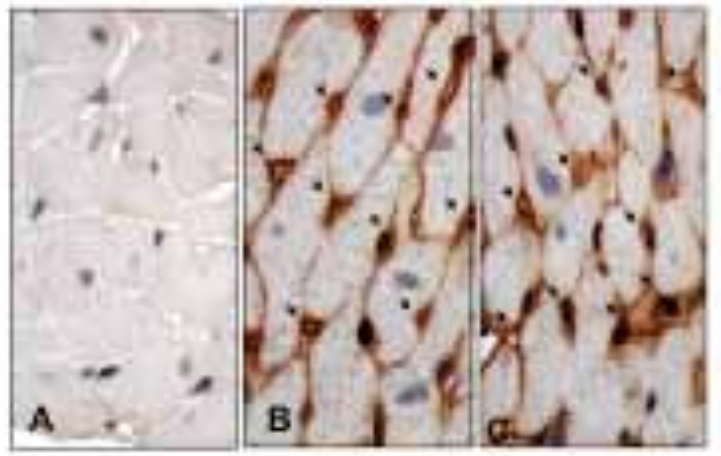

D
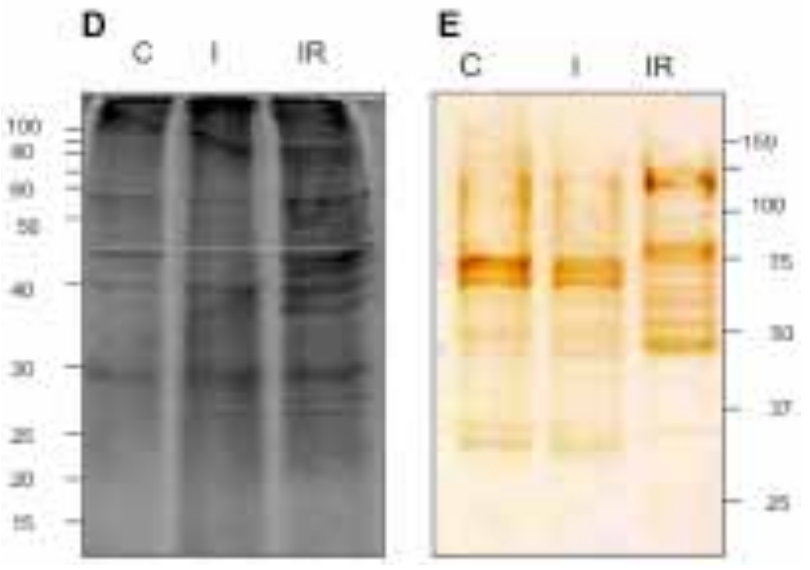

Fig. (1). Histological tissue sections: A) non-biotin labeled heart; control. B) and C) biotin perfused heart. Biotinylation; brown color, is restricted to the coronary vascular endothelium. All capillaries were labeled by the biotin (arrows). D) Electrophoretic patterns of CM protein fraction during control (C), I and I/R. E) Electrophoretic patterns of biotinylated coronary VELM. CM protein fractions from SDS-PAGE were transferred to nitrocellulose membranes and coronary VELM proteins revealed by DAB. I/R patterns (E) display more bands of low molecular weight proteins compared to $\mathrm{C}$.

with these coordinates were identified in the control biotin2D-SDS-PAGE results (Fig. 2A).

\subsection{Comparison of Protein Profile Distributions from Western Blot Biotin Analysis Studies}

To compare quantitatively and directly the differences in coronary VELM bi-dimensional $\mathrm{MW}^{-\mathrm{pH}_{\mathrm{i}}}$ distributions between control, ischemia and ischemia-reperfusion, the coordinates $\left(\mathrm{MW}, \mathrm{pH}_{\mathrm{i}}\right.$ ) of each protein-point was determined and the values plotted as shown in Fig. (4). Keep in mind that all proteins identified via biotin, were labeled during control not during ischemia nor I/R.

\subsubsection{Comparison between Control and Ischemia Graphs}

The 2 upper figures correspond to control (Fig. 4A) and ischemia (Fig. 4B). In the control graph (Fig. 4A) all points (circles and dots) are 58 protein-points present during control condition. The dots are coordinates reported for the 9 identified proteins (Fig. 4A) mentioned above. In ischemia graph (Fig. 4B) all protein-points (triangles and half filled
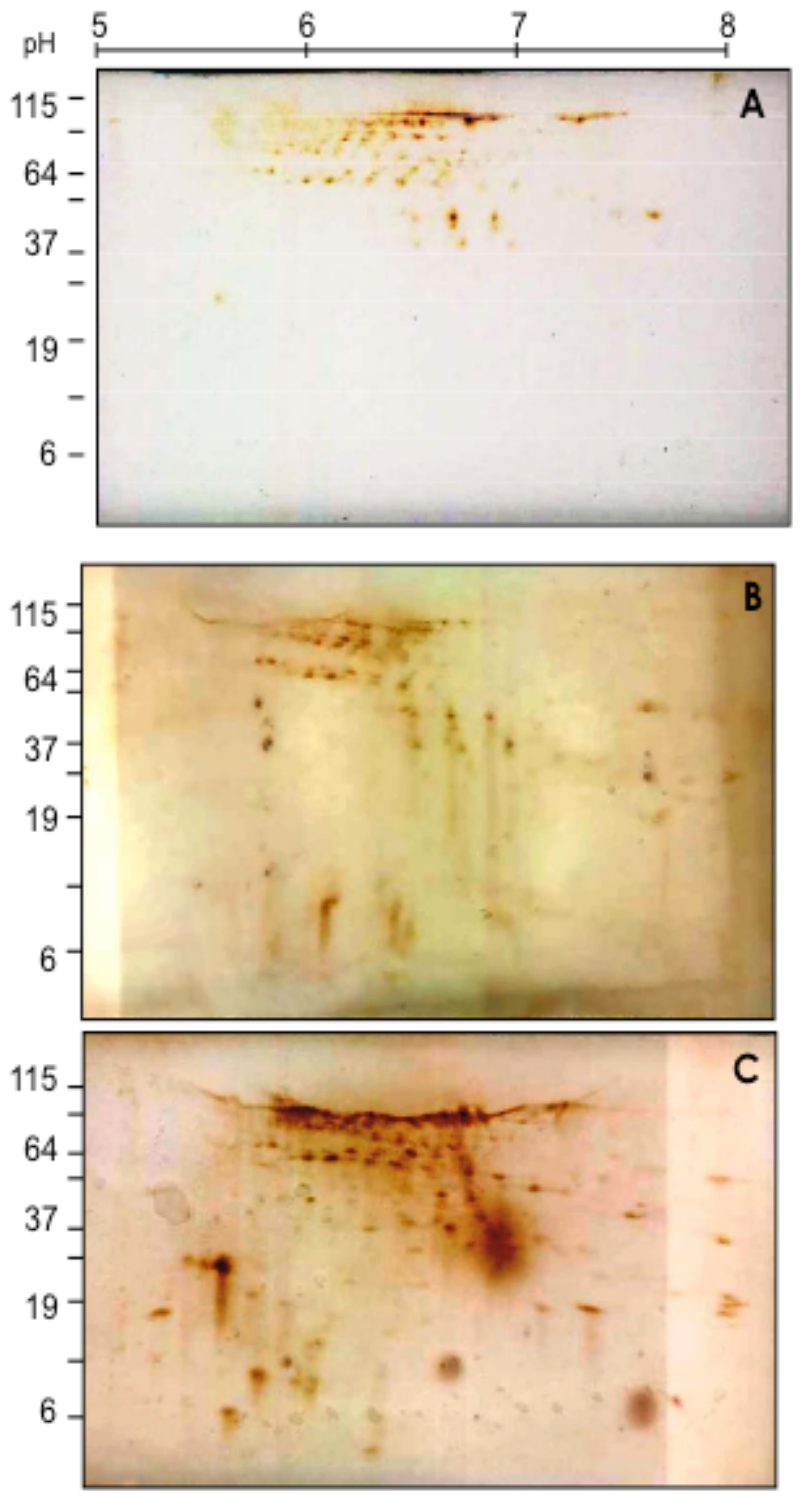

Fig. (2). 2D-SDS Western blotting patterns of biotinylated coronary VELM proteins during control (A), Ischemia (B) and I/R (C). VELM proteins were biotin labeled during control conditions. Notice that from $\mathbf{A}$ to $\mathbf{B}$ to $\mathbf{C}$ there is an increase in the number of low molecular weight spots.

triangles) present during ischemia are shown. Triangles are protein-points with different coordinates that are not present during control; i. e control proteins whose $\mathrm{MW}$ and $\mathrm{pH}_{\mathrm{i}}$ were chanced by ischemia. But, half filled triangles (20 proteinpoints) are protein-points that have the same coordinates as protein-points in the control, likely ischemia resistant proteins. These results show that only $20 / 58$ protein-points (34 $\%$ ) remain unchanged, while $66 \%$ of the protein-points their MW and pHi were altered by ischemia. None of the dots in (Fig. 4A) appear in (Fig. 4B) indicating the coordinates (MW and $\mathrm{pH}_{\mathrm{i}}$ ) of $\alpha_{1}, \beta_{1}, \mathrm{AT}_{1}$, PRL, $\mathrm{B}_{2}, \beta$ EnaC, PECAM- 1 , VCAM-1, and ICAM-1 were changed by ischemia. Clearly, transition from control to ischemia results in alteration of the MW and $\mathrm{pH}_{\mathrm{i}}$ of $66 \%$ of protein-points (ischemia susceptible proteins), while a smaller fraction of protein-points their 
coordinates remain unchanged (half filled triangles), likely ischemia resistant proteins.

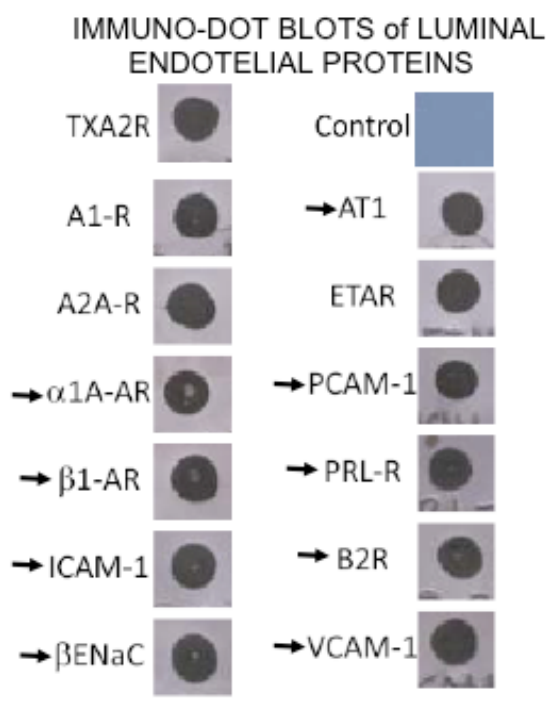

Fig. (3). By immuno-dot blot ten G-coupled hormone receptors and three adhesins proteins were identified in the coronary VELM protein fraction. The arrows indicate proteins whose $\mathrm{MW}-\mathrm{pH}_{\mathrm{i}}$ coordinates are known and in the plot $\left(\mathrm{MW}-\mathrm{pH}_{\mathrm{i}}\right)$ in figure $4 \mathrm{~A}$ were identified.
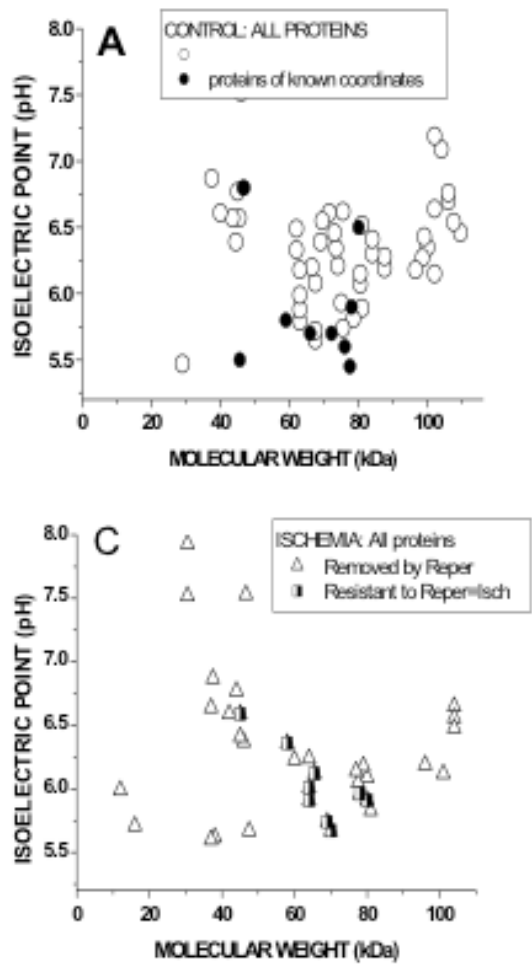

\subsubsection{Comparison between Ischemia and I/R Graphs}

The 2 lower figures correspond to ischemia (Fig. 4C=4B) and I/R (Fig. 4D). In the left graph (Fig. 4C) all proteinpoints (triangles and half-filled squares) were present during ischemia. In the right graph (Fig. 4D) all proteins-points (squares and half filled squares) were present during I/R. Transition from ischemia to I/R shows that triangles proteinpoints (Fig. 4C) are not present in I/R; I/R susceptible proteins, while half-filled squares (Figs. 4C and 4D) are 9 protein-points whose $\mathrm{MW}$ and $\mathrm{pH}_{\mathrm{i}}$ were not chanced by I/R; I/R resistant protein-points. These results show that $9 / 38$ proteinpoints $(23 \%)$ coordinates during ischemia remain unchanged, while $76 \%$ of the protein-points their $\mathrm{MW}$ and $\mathrm{pH}_{\mathrm{i}}$ were altered by $I / R$. I/R cause the appearance of a larger number of biotin-labeld low MW proteins with new coordinates (squares). Here again, transition from ischemia to $\mathrm{I} / \mathrm{R}$ results in alteration of the coordinates of $76 \%$ of proteinpoints (I/R susceptible proteins), while small number of protein-points their coordinates remain unchanged; likely IR resistant proteins. Of the 9 protein-points; I/R resistant proteins, 7 are protein-points found during control conditions. This implies that only $7 / 58$ protein-points $(12 \%)$ in control are ischemia and I/R resistant proteins and the rest $88 \%$ their MW and $\mathrm{pH}_{\mathrm{i}}$ are altered, indicating that likely non-specific hydrolizing mechanisms are activated by ischemia and I/R.
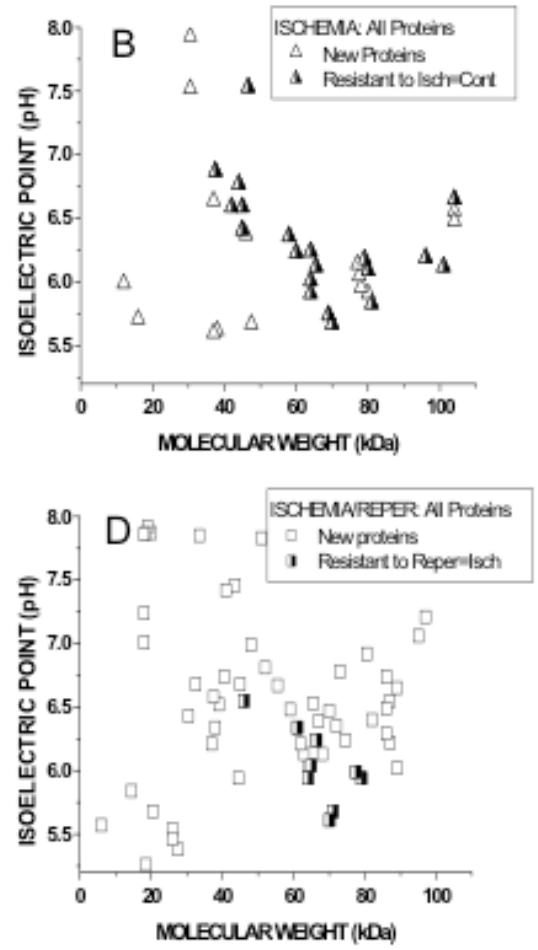

Fig. (4). Graphical representation of Molecular weights (abscissae) and Isoelectric pH (ordinates) of biotin-labled VELM proteins. Control coroanry VELM proteins (A), ischemia VELM proteins (B and C) and ischemia/reperfusion VELM proteins (D). Comparison between $\mathbf{A}$ and $\mathbf{B}$ : (A) all points (circles and half filled triangles, 58 protein-points) show the proteins identified in control. Dots are proteins whose coordinates $\left(\mathbf{M W}\right.$, $\left.\mathrm{pH}_{\mathrm{i}}\right)$ are known and correspond to: $\alpha_{1}, \beta_{1}, \mathrm{AT}_{1}, \mathrm{PRL}, \mathrm{B}_{2}, \beta$ EnaC, PECAM-1, VCAM-1, and ICAM-1. (B). All points (triangles and half filled triangles) show the proteins identified in ischemia. Half filled triangles are 20 protein-points that were not affected by the transition from control to ischemia. None of the dots in $\mathbf{A}$ appear in $\mathbf{B}$. Comparison between $\mathbf{C}(=\mathbf{B})$ and $\mathbf{D}$ : $(\mathbf{C})$ all points (Triangles and half filled squares show all the proteins identified in ischemia. Triangle points are proteins that do not appear during ischemia/reperfusion in D. (D) all points (squares and halffilled squares) show the proteins identified in ischemia/reperfusion. Half filled squares are 9 protein-points that were not affected by the transition from ischemia to ischemia/reperfusion. Of these 9 protein-points, 7 also appear in control A, i. e. are proteins resistant to ischemia and I/R. 

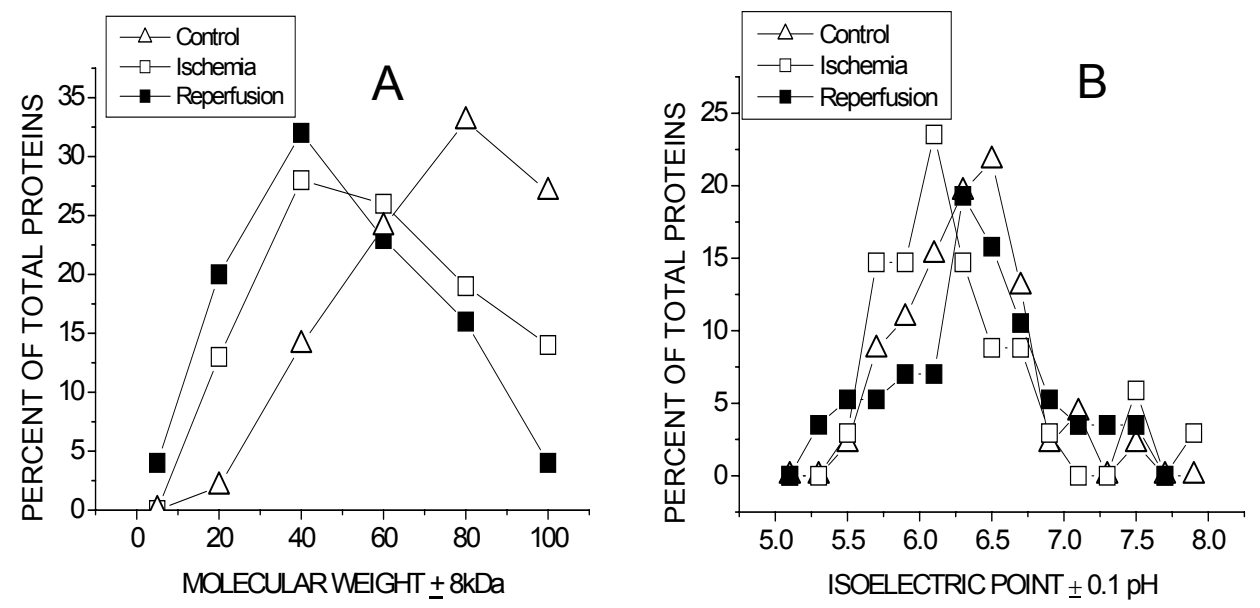

Fig. (5). Population distributions of Molecular weight (A) and isoelectric $\mathrm{pH}(\mathbf{B})$ of coronary VELM proteins during control, ischemia and ischemia/reperfusion. (A). The greatest number of proteins for control was $80 \mathrm{kD}$, for ischemia and ischemia/reperfusion the peaks were at $40 \mathrm{kD}$. The control curve for MW $>60 \mathrm{kD}$ lies above that for ischemia and even lower is the ischemia/reperfusion curve. In contrast, the control curve for $\mathrm{MW}<60 \mathrm{kD}$ lies below that for ischemia and even lower than the ischemia/reperfusion curve. (B). The control, ischemia and ischemia/reperfusion $\mathrm{pH}_{\mathrm{i}}$ curves also differ. The greatest number of proteins for control have a $\mathrm{pI}=6.40$, for ischemia and ische$\mathrm{mia} /$ reperfusion the corresponding peaks were at $\mathrm{pI}=6.0$ and $\mathrm{pI}=6.2$ respectively.

\subsection{3. $M W$ and $\mathrm{pH}_{\mathrm{i}}$ Populations Distribution Plots of Coronary Protein Points During Control, Ischemia and I/R}

Since each of the transitions from control to ischemia and from ischemia to I/R are associated with obvious $\mathrm{MW}-\mathrm{pH}_{\mathrm{i}}$ coordinate changes, we decided to analyze the data via MW (Fig. 5A) and $\mathrm{pH}_{\mathrm{i}}$ (Fig. 5B) population distribution plots. The left graph shows that during control conditions (triangles) coronary VELM proteins have a MW range between $100 \mathrm{kDa}$ to $20 \mathrm{kDa}$ with the largest proportion of proteins having a MW of about $80 \mathrm{kDa}$ and only $13 \%$ with a MW less than $60 \mathrm{kDa}$. Ischemic VELM proteins (squares) also have a MW range between $100 \mathrm{kDa}$ to $20 \mathrm{kDa}$ with the largest proportion of proteins having a MW of about $40 \mathrm{kDa}$ and $43 \%$ with a MW less than $60 \mathrm{kDa}$ i. e. there is a shift in the distribution curve to the left with fewer number of high MW proteins and more low MW proteins. The changes induced by ischemia are further amplified by I/R. Under this condition (filled squares) the MW range is also between $100 \mathrm{kDa}$ to $20 \mathrm{kDa}$ with the largest number of proteins having a MW of about $40 \mathrm{kDa}$ and there is a further shift of the distribution curve to the left with $51 \%$ of proteins having a MW less than $60 \mathrm{kDa}$.

With respect to the $\mathrm{pH}_{\mathrm{i}}$ protein population distribution plots (Fig. 4B), the majority of proteins from control hearts possess $\mathrm{pH}_{\mathrm{i}}$ in the 6-6.5 range which shifts to more acidic $\mathrm{pH}_{\mathrm{i}}$ following ischemia. Reperfusion leads to a shift in $\mathrm{pH}_{\mathrm{i}}$ distribution towards control conditions.

\section{DISCUSSION}

Our results show that coronary VELM proteins, "the luminal endothelial glycocalyx" proteins biotin-labeled during control conditions show drastic chemical changes during the successive stages of ischemia and I/R.

Our results of MW population distribution analyses show that a shift toward lower MW proteins with ischemia was further accentuated by I/R. These 2 insults also affected the $\mathrm{pH}_{\mathrm{i}}$ population distribution (control peak $\mathrm{pH}_{\mathrm{i}}=6.5$ ), ische- mia displaced the group toward a more acidic $\mathrm{pH}$ (peak $\mathrm{pH}_{\mathrm{i}}=6.0$ ) and $\mathrm{I} / \mathrm{R}$ shifted to $\mathrm{pI}=6.3$ (Fig. 5B).

In the present work, the biotin coronary VELM protein labeling method by Zhou et al., [29] was modified to be certain that during infusion, the biotin-reactive agent (SNHS-LC-biotin) was confined to the coronary intravascular space so that only VELM proteins were labeled (Fig. 1). This was achieved by adjusting 2 parameters, the intravascular concentration of the labeling agent was diluted 16 times (from $2 \mathrm{mg} / \mathrm{ml}$ to $0.125 \mathrm{mg} / \mathrm{ml}$ ) to reduce its concentration gradient and the period of S-NHS-LC-biotin perfusion was shortened from 120 to $5 \mathrm{sec}$ to reduce 24 times the diffusion period, followed by a $55 \mathrm{sec}$ wash period (6 cycles). In our hands using the conditions of Zhow et al., [33] resulted in intense labeling of all cell membranes of coronary vascular; endothelial and smooth muscle cells and the cardiac cells membranes (not shown). It is possible that these differences with Zhow et al., work may reside in differences between the vasculature of the 2 tissues. Our methodology detects only those proteins that were labeled during control conditions. Any biotin-labeled proteins identified during ischemia or I/R are to proteins labeled during control except that their MW and $\mathrm{pH}_{\mathrm{i}}$ were changed by those insults. Our procedures provide information about protein biochemical history from control to ischemia and from ischemia to $\mathrm{I} / \mathrm{R}$.

\subsection{Possible Activating Mechanisms of the Alteration of Coronary VELM Protein Profiles; An Open Question}

MW and $\mathrm{pH}_{\mathrm{i}}$ alterations of VELM population distributions induced by ischemia and I/R imply that control proteins with each successive transition: control to ischemia $(66 \%)$ and to I/R (88\%), suffer partial hydrolysis either of their proteic (both $\mathrm{MW}$ and $\mathrm{pH}_{\mathrm{i}}$ changes) or/and their oligosaccharide moieties (only MW changes). This widespread hydrolysis include a list of G-protein couple receptors and adhesive proteins (Fig. 3), indicates that hormonal activation of these VELM G-coupled receptors and adhesive proteins is altered. Evidence supports the activation by ischemia and I/R of both 
proteic and glycan hydrolyzing mechanisms [10, 20, 26, 3136]. But, the mechanisms of the activation by these insults are only suspect.

Endothelial proteic shedding has been linked to metalloproteinase (MMP) activation and their activation by schemia and I/R in heart is well documented [10, 31-36]. Specifically, MMP activity has been shown to increase following reperfusion and may be responsible for glycocalyx shedding and cleveage of the $\beta 2$-adrenergic receptor [32, 33]. But, the mechanism of MMP activation is not clear.

In contrast to protease activation by ischemia and $I / R$, activation of glycosaminoglyclans-hydrolyzing mechanisms have been inferred. Luminal endothelial glycocalyx thickness/EEZ thickness" is reduced in size if heparinase and hyaluronidase [20, 25, 27] are infused. In addition, if hyaluronidate (which competes for hydrolysis with the endogenous hyaluronidate) is infused prior to $I / R$, the EEZ thickness is not affected [20]. The activation of other types of glycanases by ischemia and I/R is suggested when exogenous lectins upon binding to protein oligosaccharides moieties protect these sites (prevent EEZ reduction) from hydrolysis by $\mathrm{I} / \mathrm{R}$ activated glycanases [24]. We have recently shown that the level of total glycosaminoglycans of coronary VELM is decreased by ischemia and I/R [36], but the glycanases involved were not identified. Evidence indicates that TNF- $\alpha$, cytokines and reactive oxygen species play an important role in I/R injury [1, 10, 20, 26, 31-35, 37]. They may be the activating agents of protein and oligosaccharide hydrolyzing enzymes in control VELM seem to be dormant.

\subsection{Possible Functional Implications of the Changes of Coronary VELM Properties Induced by Ischemia and I/R}

In proteins of the coronary VELM reside multiple functions; solute permeability, hormone reception, flow sensing, inflammation, atherosclerosis, coagulation etc, [7, 12, 13, 1719, 21-23]. These functions likely are altered from control to ischemia and to $\mathrm{I} / \mathrm{R}$ because coronary VELM protein MW and $\mathrm{pH}_{\mathrm{i}}$ profiles between control, ischemia and I/R are different.

Solute endothelial permeabilty is determined by the chemical properties and thickness of EEZ. EEZ thickness suffers important reduction in size during $I / R$ and the associated change in chemical composition (Figs. 3, 4) imply there must be important selective permeability changes $[20,26]$.

The coronary VELM is an important site of hormone reception [6, 23, 33] and flow sensing [22] a list of G-protein coupled receptors and $\beta E n a C$ a flow sensor, reside in this structure as shown above. Here we show that these estructures are cleave because their $\mathrm{MW}-\mathrm{pH}_{\mathrm{i}}$ coordinates are altered by ischemia and by I/R, implying that the pharmacology and flow sensing function of VELM are also altered. VELM proteins like PECAM-1, V-CAM-1 and ICAM-1 associated with inflammatory and coagulation processes $[17,24]$ their chemistry $\left(\mathrm{MW}\right.$ and $\left.\mathrm{pH}_{\mathrm{i}}\right)$ is also altered by ischemia and I/R so must be their function

Much remains unclear about the mechanisms involved in I/R injury. Furthermore, our data are consistent with the idea that a large modification of the glycocalyx chemistry and structure are important steps in the pathological cascade of events leading to I/R injury and infarct size. This indicates that modification of the glycocalyx is a primary component of early I/R effects and should be a therapeutic target in the prevention and/or treatment of I/R injury [1].

\section{ACKNOWLEDGEMENTS}

Funding by: CONACyT SEP-42567, CONACyT-SALUD 2004-C01-156 and Fulbright-Robles Award \#9583.

\section{CONFLICT OF INTEREST}

None.

\section{SUPPLEMENTARY MATERIAL}

Supplementary material is available on the publishers Web site along with the published article.

\section{REFERENCES}

[1] Becker BF, Chappell D, Bruegger D, Annecke T, Jacob M. Therapeutic strategies targeting the endothelial glycocalyx: acute deficits, but great potential. Cardiovasc Res 2010; 87: 300-10.

[2] Kim JS, Jin Y, Lemasters JJ. Reactive oxygen species, but not $\mathrm{Ca} 2$ overloading, trigger $\mathrm{pH}$ and mitochondrial permeability transition-dependent death of adult rat myocytes after ischemiareperfusion. Am J Physiol Heart Circ Physiol 2006; 290: H2024-34.

[3] Vilahur G, Juan-Babot O, Peña EB, Oñate B, Casaní L, Badimon L. Molecular and cellular mechanisms involved in cardiac remodeling after acute myocardial infarction. J Mol Cell Cardiol 2011; 50: 522-33.

[4] Shivakumar K, Sollott SJ, Sangeetha M, et al. Paracrine effects of hypoxic fibroblast-derived factors on the MPT-ROS threshold and viability of adult rat cardiac myocites. Am J Physiol Heart Circ Physiol 2008; 294: H2653-8.

[5] Vásquez C, Mohandas P, Louie KL, Benamer N, Bapat AC, Morley GE. Enhanced fibroblast-myocyte interactions in response to injury. Cir Res 2010; 107: 1011-20.

[6] Mebazaa A, Mayoux E, Maeda A, et al. Paracrine effects of endocardial endothelial cells on myocyte contraction mediated via endothelin. Am J Physiol Heart Circ Physiol 1993; 265: H1841-6.

[7] Rubio R, Ceballos G. Role of endothelial glycocalyx in dromotropic, inotropic, and arrythmogenic effects of coronary flow. Am J Physiol 2000: 278: H106-16.

[8] Divald A, Kivity S, Wang P, et al. Myocardial ischemic preconditioning preserves postischemic function of the proteosome through diminished oxidative damage to $19 \mathrm{~S}$ regulatory particle subunits. Cir Res 2010; 106: 1829-34.

[9] Cohen MVY, Xi-Ming Y, Downey JM. The pH Hypothesis of Postconditioning. Staccato Reperfusion Reintroduces Oxygen and Perpetuates Myocardial Acidosis. Circulation 2007; 115: 1895-903.

[10] Beresewicz A, Czarnowska E, Maczewski M. Ischemic preconditioning and superoxide dismutase protect against endothelial dysfunction and endothelium glycocalyx disruption in the postischemic guinea-pig hearts. Mol Cell Biochem 1998; 186: 87-97.

[11] Haack DW, Bush LR, Shlafer M, Lucchesi BR. Lanthanum staining of coronary microvascular endothelium: effects of ischemia reperfusion, propanolol, and atenolol. Microvas Res 1981; 21: 362-76.

[12] Van den Berg B, Vink H, Spaan JAE. The Endothelial Glycocalyx Protects Against Myocardial Edema. Circ Res 2003; 92; 592-4.

[13] Pries AP, Secomb TW, Gaehtgens P. The endothelial surface layer. Pflugers Arch 2000; 440: 653-66.

[14] Ausprunk DH, Boudreau CL, Nelson DA. Proteoglycans in the microvasculature. Am J Pathol 1981; 103: 383-6.

[15] Simionescu M, Simionescu N, Palade GE. Differentiated microdomains on the luminal surface of capillary endothelium: distribution of lectin receptors. J Cell Biol 1982; 94: 406-13. 
[16] Taylor M, Drickamer K. Introduction to Glycobiology. $2^{\text {nd }}$ ed. NY: Oxford University Press 2006; p. 255.

[17] Mulivor AW, Lipowsky HH. Role of glycocalyx in leukocyte endothelial cell adhesion. Am J Physiol Heart Circ Physiol 2002; 283: H1282-91.

[18] Vink H, Duling BR. Capillary endothelial surface layer selectively reduces plasma solute distribution volume. Am J Physiol Hear Circt Physiol 2000; 278: H285-9.

[19] Rosenberg RD. Redesigning heparin. N Engl J Med 2001; 344: 673-5.

[20] Gayosso-Rubio I, Platts SH, Duling BR. Reactive oxygen species mediate modification of glycocalyx during ischemia reperfusion injury. Am J Physiol Heart Circ Physiol 2006; 290: H2247-56.

[21] Panakis MY, Kosky JR, Dull RO, Tarbell JM. The role of endothelial glycocalyx components in mechanotransduction of fluid shear stress. Biochem Biophys Res Commun 2007; 355: 228-33.

[22] Ramiro-Diaz J, Barajas-Espinosa A, Chi-Ahumada E, et al. Luminal endothelial lectins with affinity for N-Acetylglucosamine determine flow-induced cardiac and vascular paracrine-dependent responses. Am J Physiol Heart Circ Physiol 2010; 299: 743-51.

[23] Castillo-Hernández J, Torres-Tirado D, Barajas-Espinosa A, et al. Two dissimilar AT1 agonists distinctively activate AT1 receptors located on the luminal membrane of coronary endothelium. Vasc Pharmacol 2009; 51: 314-22.

[24] Mulivor AW, Lipowsky HH. Inflammation- and ischemia-induced shedding of venular glycocalyx. Am J Physiol Heart Circ Physiol 2004; 286: H1672-80.

[25] Henry CB, Duling BR. Permeation of the luminal capillary glycocalyx is determined by hyaluronan. Am J Physiol Heart Circ Physiol 1999; 277: H508-14.

[26] Henry CB, Duling BR. TNF- $\alpha$ increases entry of macromolecules into the luminal endothelial cell glycocalyx. Am J Physiol Heart Circ Physiol 2000; 279: H2815-23.

[27] Desjardins C, Duling BR. Heparinase treatment suggests a role for the endothelial cell glycocalyx in regulation of capillary hematocrit. Am J Physiol 1990; 258: H647-54.
[28] Contastinescu AA, Vink H, Spaan JA. Elevated capillary tube hematocrit reflects degradation of endothelial cell glycocalyx by oxidized LDL. Am J Physiol Heart Circ Physiol 2001; 280: H1051-7.

[29] Zhou Y-J, Wang S-Q, Zhang W, et al. A novel method to isolate and map endothelial membrane proteins from pulmonary vasculature. Am J Physiol Cell Physiol 2004; 288: C950-6.

[30] Towbin H, Staehelin T, Gordon J. Electrophoretic transfer of proteins from polyacrylamide gels to nitrocellulose sheets: procedure and some applications. Proc Natl Acad Sci USA 1979; 76: 4350-4.

[31] Bencsik P, Kupai K, Giricz Z, et al. Role of iNOS and peroxynitrite-matrix metalloproteinase-2 signaling in myocardial late preconditioning in rats. Am J Physiol Heart Circ Physiol 2010; 299: H512-8.

[32] Romanic AM, Harrison SM, Bao W, et al. Myocardial protection from ischemia/ reperfusion injury by targeted deletion of matrix metalloproteinase-9. Cardiovas Res 2002; 54: 549-58.

[33] Rodriguez SF, Tran ED, Fortes ZB, Schmid-Schönbein GW. Matrix metalloproteinases cleave the beta2-adrenergic receptor in spontaneously hypertensive rats. Am J Physiol Heart Circ Physiol 2010; 299: H25-35.

[34] Kalogeris TJ, Korthuis RJ. Vascular receptors as new substrates for matrix metalloproteinases in hypertension and other inflammatory states. Am J Physiol Heart Circ Physiol 2010; 299: H13-5.

[35] Mulivor AW, Lipowsky HH. Inhibition of glycan shedding and leukocyte-endothelial adhesion in postcapillaryvenules by suppression of matrixmetalloprotease activity with doxycycline. Microcirculation 2009;16: 657-66.

[36] Knabb M, Pérez-Aguilar S, Torres-Tirado D, Ramiro-Díaz J, Rubio R. Biochemical alterations in coronary endothelial luminal membranes during ischemia and reperfusion in isolated perfused guinea pig hearts. FASEB J. April 2010 (Meeting Abstract Suppl) Abst 598.4, pp 1671.

[37] Visse R, Nagase H. Matrix metalloproteinases and tissue inhibitors of metalloproteinases. Structure, Function and Biochemistry. Circulation Res 2003; 92: 827-32. 